\title{
Faktor Keengganan Pelajar Bersepeda di Yogyakarta
}

\author{
Factors for Students Reluctance to Cycling in Yogyakarta
}

\author{
Isa Indrawan ${ }^{1, a)}$, Muhammad Zudhy Irawan $^{2)}$ \& Siti Malkhamah ${ }^{3)}$ \\ ${ }^{1)}$ Departemen Teknik Sipil dan Lingkungan, Fakultas Teknik, Universitas Gadjah Mada, Yogyakarta.
}

Koresponden : ${ }^{a)}$ isaindrawan@mail.ugm.ac.id

\begin{abstract}
ABSTRAK
Budaya bersepeda sebagai moda transportasi ramah lingkungan masih terus digalakkan di berbagai wilayah. Pelajar remaja tingkat Sekolah Menengah Pertama (SMP) dan Sekolah Menengah Atas (SMA) merupakan potensi besar pengguna di kota Yogyakarta, dimana secara usia dapat lebih mandiri untuk perjalanan harian sekolah. Mayoritas pelajar remaja saat ini tergantung pada kendaraan bermotor yang tidak ramah lingkungan. Untuk itu, kami berusaha menemukan faktor yang mempengaruhi penggunaan sepeda pada pelajar remaja non-pesepeda. Kami menggunakan metode analisis faktor eksploratori pada 248 responden pelajar remaja, untuk merumuskan faktor yang mempengaruhi, mulai tahap sesaat sebelum berangkat dari rumah, sampai dengan sekolah dan sebaliknya. Kami menemukan empat faktor, secara berurutan yaitu : faktor mobilitas dan aksesibilitas; faktor keamanan dan keselamatan; faktor kenyamanan; dan faktor kualitas infrastruktur bersepeda, yang mempengaruhi pelajar remaja di kota Yogyakarta enggan menggunakan sepeda untuk perjalanan sekolah. Temuan kami membuktikan bahwa manajemen mobilitas dan perilaku pengguna infrastruktur, dengan lebih banyak waktu seharian dihabiskan hanya di sekolah lebih mendorong penggunaan sepeda, dan setelahnya meningkatkan kualitas infrastruktur bersepeda lebih aman, selamat dan nyaman dapat dilakukan.
\end{abstract}

Kata Kunci : manajemen infrastruktur, perilaku pengguna infrastruktur, sepeda, pelajar remaja, analisis faktor eksploratori

\section{PENDAHULUAN}

Transportasi ramah lingkungan saat ini menjadi isu penting terkait pemanasan global, namun ketergantungan akan kendaraan bermotor tampaknya tidak bisa dilepaskan dari kehidupan masyarakat. Bagaimanapun, polusi udara merupakan indikator penting (WHO, 2018) untuk menilai tingkat kenyamanan hidup dari kota. Sepeda sebagai alat transportasi yang tidak memberikan pencemaran udara, saat ini menjadi tidak dominan penggunaannya dibandingkan dengan kendaraan bermotor. Terlebih lagi pada negara dengan tingkat ketergantungan kendaraan bermotor tinggi, dimungkinkan adanya kontribusi ekonomi-politik dari industri kendaraan bermotor (Mattioli et al., 2020). Hal tersebut mungkin berkaitan dengan pertumbuhan signifikan pada kendaraan bermotor di Indonesia, untuk rentang tahun 2014-2018 rata-rata tumbuh 6.49\% pertahun (Badan Pusat Statistik Republik Indonesia, 2018). Sangat dimungkinkan sekali dengan pertumbuhan sebesar itu, akan membuat kota-kota di Indonesia mengalami kemacetan, sehingga DKI Jakarta berada pada peringkat ke 10 kota termacet dunia, dengan tingkat kemacetan 53\% (Tomtom, 2019).

Ketergantungan akan kendaraan bermotor pada pelajar remaja, banyak pula dilaporkan di berbagai belahan dunia (Hopkins, García Bengoechea, \& Mandic, 2019; Stark, Berger, \& Hössinger, 2018). Bagaimanapun, pelajar remaja tingkat Sekolah Menengah Pertama (SMP) dan Sekolah Menengah Atas (SMA) seharusnya telah dapat mandiri untuk perjalanan sekolah 
secara usia, namun belum memenuhi persyaratan untuk dapat sepenuhnya mengendarai sendiri kendaraan bermotor, karena mayoritas masih belum memiliki Surat Izin Mengemudi (SIM). Sehingga, penggunaan sepeda merupakan alat transportasi yang sesuai untuk perjalanan sekolah, terlebih dengan peraturan zonasi sekolah maka dominan jarak tempat tinggal siswa dari sekolah < $5 \mathrm{~km}$ (Menteri Pendidikan dan Kebudayaan Republik Indonesia, 2018). Ini merupakan rentang yang efektif untuk penggunaan sepeda (Wang et al., 2018; Wuerzer \& Mason, 2015).

Saat ini, hampir setiap jalan di kota Yogyakarta memiliki lajur sepeda. Pada kenyataannya, ketergantungan terhadap kendaraan bermotor gampang sekali ditemui pada pelajar, baik dikendarai sendiri maupun diantar atau dijemput orang tua sehari-hari (Irawan \& Sumi, 2011). Terlebih, sesaat setelah SIM dimiliki, anak remaja usia SMU cenderung mengemudi kendaraan bermotor untuk perjalanan sekolah (Irawan \& Sumi, 2011; Pojani, Van Acker, \& Pojani, 2018). Kebiasaan bersepeda sejak dini dalam bertransportasi penting untuk diciptakan, karena semakin tinggi tingkat pendidikan remaja, ketergantungan kendaraan bermotor di Yogyakarta semakin meningkat pula, walaupun jarak tempuh dapat dicapai dengan berjalan kaki pada radius dibawah $1 \mathrm{~km}$, dan bersepeda dibawah $5 \mathrm{~km}$ (Devi, 2017). Ketika infrastruktur berserta fasilitas bersepeda telah tersedia, namun pelajar masih enggan untuk menggunakannya, tinjauan siklus hidup sebagai bagian dari manajemen aset infrastruktur dan fasilitas perlu dilakukan, sehingga infrastruktur dan fasilitas bersepeda dapat berfungsi baik (Soemitro \& Suprayitno, 2018; Suprayitno \& Soemitro, 2018).

Untuk itu, penelitian ini bertujuan untuk mengetahui faktor yang mempengaruhi penggunaan sepeda untuk perjalanan harian sekolah, pada pelajar remaja SMP dan SMA nonpesepeda, dan bertempat tinggal dalam jarak $<5 \mathrm{~km}$ dari sekolah. Sehingga diharapkan, setiap orang di kota Yogyakarta dapat bertransportasi dengan efektif, efisien dan ramah lingkungan.

\section{STUDI PUSTAKA}

Untuk mengeksplorasi persepsi pelajar remaja dalam penggunaan sepeda untuk perjalanan sekolah, kami mencoba mengekplorasi item-item yang difikirkan oleh pelajar, mulai dari zona asal tempat tinggal sampai dengan zona tujuan sekolah. Pilihan moda perjalanan dipengaruhi empat kelompok faktor, yaitu : ciri pengguna; ciri pergerakan; ciri fasilitas moda transportasi; dan ciri kota atau zona (Ben-Akiva dan Lerman, 1985 dalam Tamin, 2008). Aspek yang mendasari ciri pengguna merupakan representasi dari faktor-faktor sosial-demografi, seperti jenis kelamin, bentuk rumah tangga, tingkat pendidikan, pendapatan, kepemilikan SIM dan hal kepribadian lainnya dari pengguna tersebut. Kemudian, untuk ciri pergerakan terkait dengan tujuan, waktu dan jarak pergerakan. Ciri fasilitas moda transportasi terkait dengan ketersediaan keragaman alat atau moda transportasi termasuk fasilitas penunjang, biaya yang dikeluarkan, serta persepsi yang diharapkan dan kenyataan. Sedangkan, ciri kota atau zona berkaitan dengan keterkaitan jarak antara pusat-pusat konsentrasi pelayanan kota atau zona tersebut.

Untuk perjalanan harian sekolah, sesaat sebelum melakukan perjalanan sekolah, para remaja pelajar mulai merencanakan kegiatan harian mereka. Banyaknya tempat yang akan dituju dalam keseharian, menjadi dasar pelajar untuk memilih jenis moda transportasi yang sesuai untuk digunakan (García, Arroyo, Mars, \& Ruiz, 2019; Stark et al., 2018). Perlengkapan atau barang-barang yang harus selalu dibawa pelajar dalam aktifitas harian mereka, turut mempengaruhi jenis pilihan moda yang sesuai (Gutiérrez, Hurtubia, \& Ortúzar, 2020; TerrónPérez, Molina-García, Martínez-Bello, \& Queralt, 2018). Namun, kebutuhan waktu tempuh yang dibutuhkan pelajar untuk mencapai tujuan, tetap memainkan peranan pokok dalam perjalanan (Bigazzi \& Lindsey, 2019; García et al., 2019; Grigore, Garrick, Fuhrer, \& Axhausen, 2018). Kebutuhan fleksibilitas tinggi terhadap kegiatan keseharian, membuat seseorang selalu ingin untuk dapat bebas pergi kemanapun yang mereka inginkan (García et al., 
2019; Pojani et al., 2018). Ketika seseorang memiliki suatu jenis kendaraan dengan tingkatan yang lebih baik, kecenderungan untuk malu ataupun gengsi menggunakan tingkatan jenis kendaraan yang kelasnya lebih rendah akan semakin tinggi (Pojani et al., 2018). Terlebih apabila lingkungan sosial memandang strata sebagai nilai yang sangat dipertimbangkan dalam pergaulan.

Selanjutnya, sesaat setelah memutuskan pilihan jenis moda perjalanan, pelajar kemudian akan merangkum informasi yang cukup, untuk menentukan pilihan rute yang akan ditempuh selanjutnya. Gambaran pilihan rute yang akan dilalui menuju tempat tujuan, dapat diperoleh dari pengalaman sebelumnya, ataupun dengan bantuan teknologi komunikasi dan informasi yang tersedia saat ini (Grigore et al., 2018; Sharma, Nam, Yan, \& Kim, 2019).

Pilihan rute mencerminkan kebutuhan pelajar untuk mendapatkan jarak yang terdekat dari tempat asal menuju tempat tujuan. Transportasi aktif sangat berhubungan dengan kemampuan fisik, jarak menjadi faktor dominan yang mempengaruhi keputusan pemilihan moda perjalanan (Bigazzi \& Lindsey, 2019; Grigore et al., 2018; Gutiérrez et al., 2020; Sharma et al., 2019; Zhu \& Yoon, 2017). Disisi lain, kesopanan dan perhatian kendaraan bermotor terhadap pengguna transportasi aktif, terutama sepeda sebagai objek yang rentan terhadap kecelakaan, turut pula mendorong iklim yang kondusif untuk penggunaan sepeda (Asgarzadeh, Verma, Mekary, Courtney, \& Christiani, 2017; Fournier et al., 2020; Grigore et al., 2018; Maciorowski \& Souza, 2018; Meuleners et al., 2020; Ng, Debnath, \& Heesch, 2017; Pojani et al., 2018; Sharma et al., 2019; Zhu \& Yoon, 2017). Terkadang, pengemudi kendaraan bermotor sering ngebut, dan pada jalan dalam kota yang padat, sering pula tidak menjaga jarak aman, sehingga membuat resah pesepeda, terlebih pada model fasilitas dengan lajur tercampur tanpa ada pemisah fisik.

Saat perjalanan menuju tempat tujuan, kebutuhan fasilitas yang mumpuni mempengaruhi pesepeda. Sehingga cenderung menyukai pilihan rute yang nyaman, dengan permukaan yang mulus, tidak rawan kecelakaan dan sedapat mungkin menghindari kontak dengan kendaraan bermotor (Asgarzadeh et al., 2017; Grigore et al., 2018; Gutiérrez et al., 2020; Maciorowski \& Souza, 2018; Meuleners et al., 2020; Ng et al., 2017; Pitt et al., 2019; Pojani et al., 2018; Sharma et al., 2019; Swiers, Pritchard, \& Gee, 2017; Yang, Wu, Zhou, Gou, \& Lu, 2019; Zhu \& Yoon, 2017). Kekhawatiran lainnya ketika diperjalanan bagi pengguna sepeda adalah tindak kejahatan, seperti perampokan, pelecehan ataupun premanisme (Gutiérrez et al., 2020; Johansson, Hasselberg, \& Laflamme, 2010; Zhu \& Yoon, 2017).

Faktor cuaca banyak menjadi perhatian pengendara sebagai hambatan dalam penggunaannya (Asgarzadeh et al., 2017; Meuleners et al., 2020; Pojani et al., 2018; Swiers et al., 2017; Zhu \& Yoon, 2017). Sesuatu yang dilematis dalam rangka mensukseskan transportasi yang berkelanjutan dengan upaya mendorong penggunaan sepeda, faktor polusi yang dihasilkan kendaraan tentu menjadi hambatan, sehingga banyak yang enggan menggunakan sepeda (Giménez-Gaydou, Cupido dos Santos, Mendes, Frade, \& Ribeiro, 2019; Luengo-Oroz \& Reis, 2019; Luo, Boriboonsomsin, \& Barth, 2020; Maciorowski \& Souza, 2018; Pojani et al., 2018; Swiers et al., 2017). Maka, kemenerusan rute dengan lajur khusus bersepeda yang terpisah secara fisik dari kendaraan bermotor, merupakan faktor penting terkait infrastruktur pada banyak penelitian sampai dengan saat ini, dibandingkan ukuran jalan yang lebar (Asgarzadeh et al., 2017; Grigore et al., 2018; Gutiérrez et al., 2020; Maciorowski \& Souza, 2018; Meuleners et al., 2020; Pitt et al., 2019; Sharma et al., 2019; Yang et al., 2019; Zhu \& Yoon, 2017).

Bagaimanapun, karena sangat tergantung kepada kemampuan fisik untuk penggunaan sepeda, kondisi gradasi topografi sebuah wilayah turut mempengaruhi minat seseorang untuk menggunakannya (Giménez-Gaydou et al., 2019; Grigore et al., 2018; Meuleners et al., 2020; Sharma et al., 2019; Yang et al., 2019; Zhu \& Yoon, 2017). Terkait dengan kemenerusan rute, aspek fasilitas penyeberangan turut menjadi permasalahan pesepeda sebagai moda yang rentan dalam kejadian kecelakaan (Asgarzadeh et al., 2017; Grigore et al., 2018; Maciorowski \& Souza, 2018; Malkhamah, Tight, \& Montgomery, 2005; Meuleners et al., 2020; Ng et al., 2017; 
Sharma et al., 2019; Zhu \& Yoon, 2017). Kemudian sebagai kebutuhan jarak jangkauan dari pesepeda, integrasi dengan transportasi publik seperti bus atau kereta turut menjadi motivasi penggunaannya (Cheng \& Liu, 2012; Gutiérrez et al., 2020; Yang et al., 2019).

Sesampainya pesepeda ditempat tujuan, fasilitas parkir menjadi perhatian. Fasilitas keamanan sepeda yang diparkirkan dan jarak area parkir ke bangunan yang dituju (Gutiérrez et al., 2020; Sharma et al., 2019; Yang et al., 2019) merupakan kebutuhan dari pesepeda. Kemudian, sejalan dengan faktor cuaca yang terkait dengan isu pemanasan global, kebutuhan akan fasilitas tempat mandi akibat keringat, ataupun ganti pakaian akibat kehujanan di tempat tujuan, juga menjadi pertimbangan para pesepeda (Gutiérrez et al., 2020; Meuleners et al., 2020; Swiers et al., 2017).

\section{METODA}

Survey acak dilakukan dengan membagikan kertas kuisioner (off-line) maupun secara online melalui media google form, tergantung ketersediaan waktu dari pihak sekolah. Karena tidak tersedianya data sekunder yang pasti, mengenai jarak tempat tinggal siswa pada setiap sekolah, kami hanya dapat melakukan analisa terhadap 248 pelajar tingkat SMP dan SMA Negeri di kota Yogyakarta, yang tinggal dalam jarak $<5 \mathrm{~km}$ dari sekolah dan tidak menggunakan sepeda pada perjalanan harian sekolah. Untuk siswa yang menggunakan sepeda, tinggal diluar rentang jarak (> $5 \mathrm{~km}$ ), ataupun salah dalam jawaban kuisioner, yaitu sebanyak 345 responden, dikeluarkan dari sampel penelitian. Sekolah Negeri dipilih terkait erat dengan peraturan zonasi dari Pemerintah Republik Indonesia, dimana mayoritas siswa seharusnya tinggal dalam jarak tersebut.

Dalam mencapai tujuan penelitian, kami menggunakan metode Exploratory Factor Analysis (EFA) untuk mengkonstruksi variabel laten penggunaan sepeda pada pelajar remaja. Karakteristik demografi pelajar juga menjadi bagian dalam pertanyaan untuk memastikan keberagaman responden dalam analisa, yang ditampilkan dalam Table 1. Selain itu, kami melakukan eksplorasi terhadap persepsi pelajar remaja non-pesepeda dalam perjalanan menggunakan sepeda, dari tempat tinggal sampai dengan sekolah dan sebaliknya. Aitem-aitem yang diidentifikasi dari kajian literatur menjadi dasar instrumen pertanyaan dalam kuisioner, dan disusun berdasarkan tahapan perjalanan. Kami menggunakan skala Likert's dari 1 sampai dengan 5 ( 1 = sangat setuju; $2=$ setuju; $3=$ netral; 4 = tidak setuju; dan $5=$ sangat tidak setuju) pada pilihan jawaban dalam butir pertanyaan negatif sebagaimana Table 2 .

EFA menuntut adanya validitas dan reabilitas pada alat pengukuran, untuk mengukur validitas dilakukan dengan melakukan korelasi antar setiap nilai butir pertanyaan dengan nilai total variabel konstruk (Ghozali, 2009). Sedangkan ketentuan validitas yaitu nilai signifikansi pearson product moment atau $\mathrm{r}$ hitung $>\mathrm{r}$ tabel dan sebaliknya. Kemudian untuk mengukur reabilitas antar butir ditunjukkan oleh nilai cronbach alpha dengan ketentuan reliabel apabila nilainya $>0,60$ dan sebaliknya.

Terdapat tujuh tahap dasar dalam EFA (DeCoster, 1998), yaitu : mengumpulkan variabel pengukuran; menyusun matrik korelasi; memilih jumlah faktor yang layak; mengekstraksi sejumlah faktor awal; perotasian sejumlah faktor awal; menginterpretasikan struktur faktor; dan membangun skor faktor untuk dapat dilakukan analisis lanjutan. Sejumlah kendala yang sering ditemukan pada penggunaan sepeda dari kajian literatur, dikelompokkan sebagai aitem awal untuk mendapatkan faktor umum (common factor). Kemudian matrik korelasi disusun untuk mengetahui hubungan dari masing-masing variabel, yang ditunjukkan oleh nilai Determinan of Correlation Matrix, dimana semakin mendekati 0 (nol) maka korelasi saling terkait.

Selanjutnya untuk memilih sejumlah aitem optimal juga ditentukan oleh : nilai Kaiser Meyer Olkin Measure of Sampling (KMO) dengan ketentuan > 0,50; nilai Bartlett Test of Sphericity dengan ketentuan $<0,050$ (sesuai dengan tingkat signifikansi penelitian ini); nilai 
Measures of Sampling Adequacy (MSA) dengan ketentuan > 0,50; dan nilai Communalities dengan ketentuan $>0,50$. Aitem yang tidak memenuhi syarat kemudian dikeluarkan dari pengukuran untuk mendapatkan aitem optimal.

Metode ekstraksi yang digunakan dalam penelitian ini adalah Principal Component, dengan pendekatan Eigen Value > 1,00 dalam memilih aitem yang dimasukkan kedalam analisis faktor selanjutnya. Sedangkan untuk menyederhanakan dan memperjelas aitem-aitem yang berkorelasi sejenis kedalam sebuah faktor yang sama, digunakan metode Orthogonal Rotation Varimax. Kemudian penamaan struktur faktor baru dilakukan dengan menginterpretasikan kriteria kunci dari masing-masing aitem optimal terpilih, yang mencerminkan muatan global yang terkandung dalam struktur faktor baru tersebut.

\section{ANALISIS PENELITIAN}

\section{Deskriptif}

Setelah mengeluarkan sejumlah responden yang salah dalam menjawab kuisioner penelitian, tinggal pada jarak $>5 \mathrm{~km}$ dan menggunakan sepeda, sebagaimana ditunjukkan Tabel 1, tersisa 62,50 \% pelajar SMP dan 37,50 \% pelajar SMA, dari total 248 responden. Sebagian besar responden perempuan (67.34\%) dan laki-laki (32.66\%), dimana sebagian besar tinggal dalam jarak optimal 1-3 km (48.79\%) untuk bersepeda.

Namun mayoritas pelajar diantar kesekolah dengan menggunakan sepeda motor $(\mathrm{N}=162$, atau $63.31 \%$ ) untuk perjalanan sekolah, ini menyiratkan kecilnya kemandirian pelajar dalam perjalanan sekolah dan kuatnya ketergantungan pada kendaraan bermotor. Sesaat kepemilikan SIM, baik SIM C dan SIM A, pelajar cenderung mengendarai sepeda motor $(\mathrm{N}=52$, atau 22.97 $\%$ ), namun tampaknya pelajar melakukan pelanggaran dalam syarat dasar ketentuan mengemudi yaitu kepemilikan SIM, dimana hanya 21 pelajar yang memiliki SIM C. Hal tersebut juga mengungkapkan orang tua cenderung menutup mata terhadap pelanggaran tersebut, dan mendorong pelajar untuk menggunakan kendaraan bermotor, walaupun dimungkinkan pelajar tersebut telah berusia $\geq 16$ tahun (30.24\%). Ketergantungan ini masih sejalan dengan Irawan \& Sumi, (2011), serta persepsi niat remaja untuk mengendarai kendaraan bermotor sebagaimana temuan dari Pojani et al., (2018) setelah mereka memenuhi persyaratan mengemudi. Program ataupun kampanye tertib berlalu lintas dipandang perlu dilakukan segera, tidak hanya kepada siwa tetapi juga kepada para orang tua juga. Peran sekolah juga turut menjadi penting untuk memfilter pelanggaran tersebut, sehingga siswa yang mengemudikan kendaraan bermotor pribadi, benar-benar memenuhi persyaratan untuk berkendaraan, terlebih terdapat 8 orang siswa tingkat SMP yang menggunakan sepeda motor untuk perjalanan sekolah.

Walaupun pada Tabel 2 mengungkapkan pelajar remaja non-sepeda sebenarnya tidak memiliki masalah gengsi, untuk menggunakan sepeda pada perjalanan harian sekolah $(\mathrm{M}=$ 3,83; S.D. = 0,979), hal ini juga menunjukkan aitem yang paling mudah untuk diatasi oleh mereka. Sedangkan masalah keterbatasan waktu $(M=2,16 ;$ S.D. $=0,989)$ merupakan masalah terbesar mereka dalam penggunaan sepeda untuk perjalanan sekolah. Hal tersebut sedikit kontradiksi dengan kegiatan harian yang dapat ditunjukkan oleh aitem banyak tempat yang harus dituju dalam sehari $(M=3,14$; S.D. $=1,148)$ dan aitem tidak bebas pergi kemana pun $(M$ $=3,15 ;$ S.D. $=1,106)$, yang masuk dalam jajaran aitem mudah untuk mereka atasi dalam penggunaan sepeda. Untuk itu, sekolah perlu dapat mengambil peran dengan reward kepada pengguna transportasi aktif, maupun subsidi karbon ataupun parkir dari para pelajar pengguna kendaraan pribadi.

\section{Analisis Faktor}

Analisis faktor eksploratori dilakukan dalam serangkaian proses setelah sebelumnya dilakukan uji validitas dan uji reabilitas. Hasil uji validitas menunjukkan keseluruhan 20 aitem valid pada tingkat signifikansi item correlation $>0,05$ dan reabilitas dengan nilai cronbach 
alpha total aitem 0,848 (> 0,60). Namun, tidak keseluruhan 20 aitem awal memenuhi syarat untuk dilakukan analisis faktor eksploratori untuk mendapatkan faktor (variabel laten), hanya tersisa 13 aitem yang layak untuk dilanjutkan ke dalam analisis faktor sebagaimana Tabel 3. Validitas korelasi antar aitem saling terkait ditunjukkan dengan nilai determinasi 0,037 (mendekati 0,00), nilai KMO sebesar 0,779 (> 0,50) dan nilai Bartlett Test sebesar 0,000 (< $0,05)$.

Tabel 1. Deskripsi responden

\begin{tabular}{|c|c|c|c|c|c|c|c|c|}
\hline \multirow[b]{2}{*}{ Variabel } & \multicolumn{6}{|c|}{ Pilihan Moda } & \multicolumn{2}{|c|}{ Total } \\
\hline & $\begin{array}{c}\text { Sepeda } \\
\text { motor }\end{array}$ & $\begin{array}{c}\text { Diantar } \\
\text { dengan } \\
\text { sepeda } \\
\text { motor }\end{array}$ & Mobil & $\begin{array}{c}\text { Diantar } \\
\text { dengan } \\
\text { mobil }\end{array}$ & $\begin{array}{c}\text { Trans } \\
\text { Jogja }\end{array}$ & $\begin{array}{c}\text { Ojek } \\
\text { Online }\end{array}$ & $\mathbf{N}$ & $\%$ \\
\hline \multicolumn{9}{|l|}{ Tingkat sekolah } \\
\hline SMP & 8 & 127 & 0 & 7 & 2 & 11 & 155 & $62,50 \%$ \\
\hline SMA & 44 & 35 & 2 & 9 & 0 & 3 & 93 & $37,50 \%$ \\
\hline \multicolumn{9}{|l|}{ Jenis kelamin } \\
\hline Laki-laki & 20 & 55 & 0 & 2 & 1 & 3 & 81 & $32,66 \%$ \\
\hline Perempuan & 32 & 107 & 2 & 14 & 1 & 11 & 167 & $67,34 \%$ \\
\hline \multicolumn{9}{|l|}{ Usia } \\
\hline$<16$ tahun & 10 & 133 & 1 & 14 & 2 & 13 & 173 & $69,76 \%$ \\
\hline$\geq 16$ tahun & 42 & 29 & 1 & 2 & 0 & 1 & 75 & $30,24 \%$ \\
\hline \multicolumn{9}{|l|}{ Jarak rumah-sekolah } \\
\hline$<1 \mathrm{~km}$ & 8 & 40 & 0 & 1 & 0 & 1 & 50 & $20,16 \%$ \\
\hline $1-3 \mathrm{~km}$ & 21 & 81 & 1 & 7 & 1 & 10 & 121 & $48,79 \%$ \\
\hline $3-5 \mathrm{~km}$ & 23 & 41 & 1 & 8 & 1 & 3 & 77 & $31,05 \%$ \\
\hline \multicolumn{9}{|l|}{ Kapabilitas bersepeda } \\
\hline Ya & 52 & 144 & 2 & 15 & 2 & 14 & 229 & $92,34 \%$ \\
\hline Tidak & 0 & 18 & 0 & 1 & 0 & 0 & 19 & $7,66 \%$ \\
\hline \multicolumn{9}{|l|}{ Kepemilikan SIM } \\
\hline Tidak & 31 & 159 & 1 & 15 & 2 & 14 & 222 & $89,52 \%$ \\
\hline SIM C & 18 & 3 & 0 & 0 & 0 & 0 & 21 & $8,47 \%$ \\
\hline SIM A & 0 & 0 & 1 & 0 & 0 & 0 & 1 & $0,40 \%$ \\
\hline SIM C dan SIM A & 3 & 0 & 0 & 1 & 0 & 0 & 4 & $1,61 \%$ \\
\hline \multicolumn{9}{|l|}{ Kedua orang tua bekerja } \\
\hline Ya & 35 & 123 & 1 & 12 & 2 & 12 & 185 & $74,60 \%$ \\
\hline Tidak & 17 & 39 & 1 & 4 & 0 & 2 & 63 & $25,40 \%$ \\
\hline \multicolumn{9}{|l|}{ Uang saku perhari } \\
\hline$<$ Rp. $10.000,00$ & 14 & 72 & 1 & 2 & 2 & 1 & 92 & $37,10 \%$ \\
\hline Rp. $10.000,00-15.000,00$ & 14 & 41 & 0 & 1 & 0 & 3 & 59 & $23,79 \%$ \\
\hline Rp. $15.000,00-20.000,00$ & 15 & 37 & 0 & 8 & 0 & 6 & 66 & $26,61 \%$ \\
\hline$>$ Rp. $20.000,00$ & 9 & 12 & 1 & 5 & 0 & 4 & 31 & $12,50 \%$ \\
\hline
\end{tabular}

Kami menggunakan metode extraksi Principal Component Analysis, dan faktor yang terbentuk harus dapat menjelaskan varian dari aitem, dengan ketentuan nilai eigen yang memenuhi syarat yaitu $>1$. Pada Tabel 4 , hasil analisis membentuk 4 faktor (variabel laten) yang dapat menjelaskan varian dari aitem sebesar 60,863\% (> 60\%). Dimana faktor pertama dapat menjelaskan varian sebesar 29,766 \%, faktor kedua dapat menjelaskan varian sebesar $12,955 \%$, faktor ketiga dapat menjelaskan varian sebesar $10,178 \%$, faktor keempat dapat menjelaskan varian sebesar 7,963\%, masing-masing dari keseluruhan aitem optimal. 
Sedangkan sisanya sebesar 39,137 \% di jelaskan oleh variabel lain diluar keempat faktor tersebut dikarenakan nilai eigen $<1$.

Tabel 2. Deskripsi respon terhadap aitem

\begin{tabular}{|c|c|c|c|}
\hline \multicolumn{4}{|l|}{ Saya tidak menggunakan sepeda ke sekolah karena : } \\
\hline \multicolumn{4}{|l|}{ Skala Likert's 1-5 (1=Sangat Setuju s./d. 5=Sangat Tidak Setuju) } \\
\hline Aitem & Mean & S.E. & S.D. \\
\hline Banyak tempat yang harus dituju dalam sehari & 3.14 & 0.073 & 1.148 \\
\hline Sulit membawa bermacam perlengkapan sekolah & 2.22 & 0.062 & 0.970 \\
\hline Waktu terbatas & 2.16 & 0.063 & 0.989 \\
\hline Tidak bebas pergi kemana pun & 3.15 & 0.070 & 1.106 \\
\hline Gengsi & 3.83 & 0.062 & 0.979 \\
\hline Tidak didukung informasi jalur/ rute yang handal & 3.16 & 0.062 & 0.977 \\
\hline Melelahkan & 2.27 & 0.063 & 0.993 \\
\hline $\begin{array}{l}\text { Rute tidak aman (rawan kecelakaan/ jalan berlubang/ bercampur dengan } \\
\text { kendaraan bermotor) }\end{array}$ & 2.87 & 0.069 & 1.083 \\
\hline $\begin{array}{l}\text { Kendaraan bermotor tidak peduli dengan sepeda (ngebut/ tidak jaga jarak/ } \\
\text { membuat resah) }\end{array}$ & 2.72 & 0.066 & 1.045 \\
\hline Tidak mendapat prioritas di jalan & 2.71 & 0.062 & 0.981 \\
\hline Rawan tindak kejahatan (penculikan/ perampokan/ pelecehan/ premanis me) & 3.03 & 0.068 & 1.066 \\
\hline Faktor cuaca (panas/ hujan/ tidak teduh) & 2.44 & 0.056 & 0.875 \\
\hline Terpapar polusi kendaraan bermotor & 2.37 & 0.060 & 0.943 \\
\hline $\begin{array}{l}\text { Lajur sepeda tidak nyaman (sempit/ tidak menerus/ marka dan rambu tidak } \\
\text { lengkap/ pilihan rute sedikit) }\end{array}$ & 2.75 & 0.067 & 1.061 \\
\hline Banyak turunan/ tanjakan di perjalanan & 3.17 & 0.059 & 0.928 \\
\hline Sulit menyeberang jalan & 2.68 & 0.068 & 1.076 \\
\hline Sulit membawa sepeda di bis Trans Jogja & 2.76 & 0.076 & 1.190 \\
\hline Parkir sepeda tidak aman & 3.61 & 0.064 & 1.004 \\
\hline Parkiran jauh & 3.65 & 0.047 & 0.738 \\
\hline Sulit mandi/ganti pakaian di sekolah jika pakaian basah (keringat/ hujan) & 2.81 & 0.070 & 1.097 \\
\hline Valid $N$ & 248 & & \\
\hline
\end{tabular}

Metode ekstraksi menggunakan Orthogonal Rotation Varimax with Kaiser Normalization, untuk memaksimalkan pengelompokan variabel kedalam faktor, hasil rotasi ditunjukkan oleh Tabel 5. Pengelompokan variabel kedalam faktor didasarkan pada korelasi terhadap nilai muatan faktor. Tidak bebas pergi kemana pun dengan muatan faktor 0,759 ; banyak tempat yang harus dituju dalam sehari dengan muatan faktor 0,735 ; sulit membawa bermacam perlengkapan sekolah dengan muatan faktor 0,709; dan waktu terbatas dengan muatan faktor 0,675 , memiliki muatan lebih besar terhadap komponen faktor pertama sedangkan nilai muatan mereka terhadap komponen faktor kedua, ketiga dan dan keempat memiliki nilai yang lebih kecil, maka keempat aitem tersebut membentuk faktor pertama, demikian seterusnya untuk aitem-aitem lainnya terhadap komponen faktor yang mereka bentuk.

Penamaan mobilitas dan aksesibilitas untuk faktor pertama merupakan representasi kemampuan pelajar dari banyaknya tempat yang harus dituju dan kemudahan untuk bebas pergi ke berbagai tempat, kemudian perlengkapan sekolah yang rutin mereka butuhkan setiap hari, serta limit waktu yang dihabiskan dalam menggunakan sepeda untuk perjalanan harian sekolah. Kami mendahulukan mobilitas daripada aksesibilitas karena didukung oleh banyak tempat yang dituju menyumbangkan 60,7 \% yang merupakan sumbangan terbesar, kemudian kesulitan membawa perlengkapan sekolah sebesar 58,3 \%, sedangkan sisanya yaitu kebebasan 
berpergian 59,6 \% dan kebutuhan waktu perjalanan 59,5\% merupakan representasi dari aksesibilitas. Walaupun muatan faktor tidak bebas pergi kemanapun memiliki nilai korelasi terbesar $(0,759)$ terhadap faktor, tetapi kebutuhan waktu memiliki nilai korelasi terkecil $(0,675)$, sehingga secara total korelasi aksesibilitas lebih kecil dari mobilitas. Dengan nilai varians faktor sebesar $29.766 \%$ memaknai bahwa masalah mobilitas dan aksesibilitas menjadi sangat penting untuk ditangani terlebih dahulu dibandingkan faktor lainnya. Semakin beragamnya kegiatan pelajar di banyak tempat akan sangat berpengaruh pada faktor ini, beruntung dengan penerapan 5 hari sekolah maka mayoritas pelajar akan berada di sekolah. Mobilitas dan aksesibilitas tidak terlepas dalam standar layanan utama perencanaan moda transportasi di perkotaan (Austroads, 2015). Sebagaimana mobilitas merupakan kemampuan seseorang untuk bergerak, sedangkan aksesibilitas merupakan kemudahan pencapaian tempat tekait jarak dan waktu (Tamin, 2008), maka perlu diformulasikan manajemen pola-pola kegiatan pendukung pembelajaran, dengan sekolah sebagai angker utama.

Tabel 3. Nilai measures of sampling adequacy (MSA)

\begin{tabular}{|l|}
\hline \multicolumn{1}{c|}{ Aitem Optimal } \\
\hline Tidak mendapat prioritas di jalan \\
\hline Sulit mandi/ganti pakaian di sekolah jika pakaian basah (keringat/ hujan) \\
\hline Banyak turunan/ tanjakan di perjalanan \\
\hline $\begin{array}{l}\text { Kendaraan bermotor tidak peduli dengan sepeda (ngebut/ tidak jaga jarak/ } \\
\text { membuat resah) }\end{array}$ \\
\hline Terpapar polusi kendaraan bermotor \\
\hline Sulit membawa bermacam perlengkapan sekolah \\
\hline Faktor cuaca (panas/ hujan/ tidak teduh) \\
\hline $\begin{array}{l}\text { Rute tidak aman (rawan kecelakaan/ jalan berlubang/ bercampur dengan } \\
\text { kendaraan bermotor) }\end{array}$ \\
\hline Banyak tempat yang harus dituju dalam sehari \\
\hline Waktu terbatas \\
\hline Rawan tindak kejahatan (penculikan/ perampokan/ pelecehan/ premanisme) \\
\hline Parkir sepeda tidak aman \\
\hline Tidak bebas pergi kemana pun \\
\hline
\end{tabular}

Tabel 4. Total variance explained

\begin{tabular}{|c|r|r|r|}
\hline \multirow{2}{*}{ Component } & \multicolumn{3}{|c|}{ Initial Eigenvalues } \\
\cline { 2 - 4 } & \multicolumn{1}{|c|}{ Total } & \% of Variance & Cumulative \% \\
\hline 1 & 3,870 & 29,766 & 29,766 \\
\hline 2 & 1,684 & 12,955 & 42,722 \\
\hline 3 & 1,323 & 10,178 & 52,900 \\
\hline 4 & 1,035 & 7,963 & 60,863 \\
\hline
\end{tabular}

Sejalanan dengan keamanan dan keselamatan rute menjadi faktor terbesar kedua dengan varians sebesar $12.955 \%$ dari model yang dapat mendukung kemauan bersepeda dari pelajar SMP dan SMA. Rasa aman dari kecelakaan berkorelasi paling tinggi (0.778) dengan faktor, sehingga pembenahan untuk menurunkan persepsi bahaya bagi pesepeda perlu dilakukan. Kesadaran serta kepedulian berlalulintas yang baik dari pengendara kendaraan bermotor juga 
berkorelasi (0.776) dengan faktor keamanan dan keselamatan pesepeda. Tindak kejahatan turut menjadi perhatian pelajar berkaitan (0.651) dengan keamanan dan keselamatan dalam perjalanan bersepeda harian sekolah. Norma sosial dari pengguna kendaraan bermotor, dengan memberikan prioritas kepada yang lebih rentan sesama pengguna jalan, juga memiliki hubungan (0.551) dengan faktor kemanan dan keselamatan. Dalam perencanaan infrastruktur pesepeda, faktor kemanan dan keselamatan turut memerankan peranan penting, baik dipersimpangan maupun pada badan jalan (Asgarzadeh et al., 2017; Austroads, 2015; Yang et al., 2019).

Tabel 5. Bentuk Faktor dan Penamaan

\begin{tabular}{c|cc}
\hline $\begin{array}{c}\text { Komponen } \\
\text { (Penamaan) }\end{array}$ & \multicolumn{1}{c|}{ Variabel } & $\begin{array}{c}\text { Muatan } \\
\text { Faktor }\end{array}$ \\
\hline Faktor 1 & Tidak bebas pergi kemana pun & 0,759 \\
\hline (Mobilitas dan aksesibilitas) $)$ & Banyak tempat yang harus dituju dalam sehari & 0,735 \\
\hline & Sulit membawa bermacam perlengkapan sekolah & 0,709 \\
\hline & Waktu terbatas & 0,675 \\
\hline Faktor 2 & Rute tidak aman (rawan kecelakaan/ jalan berlubang/ & 0,778 \\
\hline Keamanan dan keselamatan) & Kendaraan bermotor tidak peduli dengan sepeda (ngebut/ & 0,776 \\
\hline & Rawan tindak kejahatan (penculikan/ perampokan/ & 0,651 \\
\hline & Tidak mendapat prioritas di jalan & 0,551 \\
\hline Faktor 3 & Terpapar polusi kendaraan bermotor & 0,787 \\
\hline (Kenyamanan) & Faktor cuaca (panas/ hujan/ tidak teduh) & 0,739 \\
\hline Faktor 4 & Sulit mandi/ ganti pakaian di sekolah jika pakaian basah & 0,729 \\
\hline & Parkir sepeda tidak aman & 0,784 \\
\hline (Kualitas infrastruktur) & Banyak turunan/ tanjakan di perjalanan & 0,717 \\
\hline
\end{tabular}

Responden pelajar menyadari polusi kendaraan berkorelasi (0.787) karena menggangu kenyamanan pesepeda, terlebih saat ini jalur sepeda yang ada hanya dipisahkan oleh marka. Penanganan terhadap faktor cuaca juga penting (0.739) bagi pesepeda sebagai moda transportasi aktif. Pada akhirnya terkait dengan dampak faktor cuaca, kemudahan untuk berganti pakaian apabila berbau keringat, atau basah akibat hujan di sekolah menjadi penunjang (0.729) yang dibutuhkan pelajar untuk kenyamanan bersepeda. Dari kesemua hal tersebut, persepsi kenyamanan dalam menggunakan sepeda menjelaskan varians sebesar $10.178 \%$ dalam model, merupakan faktor penting ketiga yang dibutuhkan pelajar. Bagaimanapun, untuk mendorong penggunaan sepeda, kenyamanan termasuk didalamnya ketersediaan fasilitas penunjang, harus lebih menarik dibandingkan moda transportasi lainnya, sehingga prilaku bersepeda dapat diciptakan (Yang et al., 2019).

Fasilitas parkir sepeda tidak hanya dibutuhkan keberadaannya, namun sampai dengan tingkat kemanan terkait (0.784) dengan faktor ke empat. Ditambah dengan kebutuhan tingkat kelandaian jalur turut mendukung (0.717) penggunaan sepeda ke sekolah. Maka dari itu kualitas infrastruktur yang ada menjadi faktor ke empat, dengan varians sebesar $7.963 \%$ untuk pelajar bersepeda ke sekolah. Pada akhirnya kualitas infrastruktur bersepeda turut pula menjadi penunjang ketiga faktor sebelumnya, sehingga ketersediaan infrastruktur, pemeliharaannya, sampai dengan tingkat kualitas layanan yang baik menjadi faktor pendorong penggunaan sepeda (Sharma et al., 2019).

\section{KESIMPULAN}

Untuk mendorong penggunaan sepeda dan kemandirian pelajar SMP dan SMA nonpesepeda, yang selama ini mayoritas diantar dengan sepeda motor, mobilitas dan aksesibilitas 
merupakan faktor utama untuk didahulukan. Manajemen mobilitas dan perilaku pengguna dengan pemadatan kegiatan harian yang menghabiskan waktu siang hari pelajar, mayoritas hanya di sekolah atau sedikit tempat penting dilakukan. Sehingga, dengan pengaturan jadwal mata pelajaran yang tidak beragam dalam sehari, dapat meminimalisir beban perlengkapan sekolah terutama buku-buku atau lainnya yang wajib dibawa oleh pelajar.

Seiring dengan persepsi keamanan dan keselamatan yang lebih dominan sebagai faktor eksternal dari pesepeda, perlu dilakukan peningkatan terhadap jalur sepeda yang ada di kota Yogyakarta. Pembinaan berlalulintas kendaraan bermotor ataupun penerapan hukum, tidak hanya pada pelajar tetapi juga para orang tua. Peraturan prioritas yang mendukung bersepeda sebagai moda transportasi juga menjadi perhatian.

Kenyamanan bersepeda perlu didukung pula oleh kondisi lajur sepeda yang baik, dan pada akhirnya kualitas infrastruktur yang mendukung bersepeda penting untuk diperhatikan. Karena, penyediaan kualitas infrastruktur bersepeda yang baik termasuk perawatan dan tingkat layanan, merupakan penunjang ketiga faktor lainnya.

Sebagaimana total komulatif varian yang didapat dari penelitian ini hanya dapat menjelaskan $60.863 \%$ dan sebanyak 7 aitem gugur dalam analisa yang kami lakukan, maka pengembangan dari model perlu untuk dilakukan. Selain itu perlu juga dilakukan penerapannya di kota ataupun kawasan lain yang berbeda karakteristiknya dari kota Yogyakarta, tentu saja dengan menambah variasi aitem yang belum kami lakukan terkait nilai komulatif varian dan aitem yang gugur.

CATATAN. Terima kasih kami ucapkan kepada Pusbindiklatren Bappenas yang telah memberikan bantuan pendanaan sehingga penelitian kami dapat terlaksana.

\section{DAFTAR PUSTAKA}

Asgarzadeh, M., Verma, S., Mekary, R. A., Courtney, T. K., \& Christiani, D. C. (2017). The role of intersection and street design on severity of bicycle-motor vehicle crashes. Injury Prevention, 23(3), 179-185. Diambil 10 Desember 2019 dari https://doi.org/10.1136/injuryprev-2016-042045

Austroads. (2015). Level of Service Metrics ( for Network Operations Planning ). (D. Green \& I. Espada,Ed.). Sidney, Australia: Austroads Ltd. Diambil dari www.austroads.com.au

Badan Pusat Statistik Republik Indonesia. (2018). Statistik Transportasi Darat 2018. (Subdirektorat Statistik Transportasi,Ed.). Diambil dari Jakarta: BPS RI/BPS-Statistics Indonesia:

https://www.bps.go.id/publication/2019/11/27/7fdd3379108b4a60e046f4c8/statistiktransportasi--darat--2018.html

Bigazzi, A., \& Lindsey, R. (2019). A utility-based bicycle speed choice model with time and energy factors. Transportation, 46(3), 995-1009. Diambil dari https://doi.org/10.1007/s11116-018-9907-2

Cheng, Y. H., \& Liu, K. C. (2012). Evaluating bicycle-transit users' perceptions of intermodal inconvenience. Transportation Research Part A: Policy and Practice, 46(10), 1690-1706. Diambil dari https://doi.org/10.1016/j.tra.2012.10.013

DeCoster, J. (1998). Overview of Factor Analysis Jamie. Diambil 15 Desember 2019, dari http://www.stat-help.com/notes.html

Devi, M. K. (2017). Potential to increase active commuting level in university area (Case study: Universitas Gadjah Mada). IOP Conference Series: Earth and Environmental Science, 70(1). Diambil dari https://doi.org/10.1088/1755-1315/70/1/012022

Fournier, N., Bakhtiari, S., Valluru, K. D., Campbell, N., Christofa, E., Roberts, S., \& Knodler, M. (2020). Accounting for drivers' bicycling frequency and familiarity with bicycle infrastructure treatments when evaluating safety. Accident Analysis and Prevention, 
137(December 2019), 105410. Diambil dari https://doi.org/10.1016/j.aap.2019.105410

García, J., Arroyo, R., Mars, L., \& Ruiz, T. (2019). The influence of attitudes towards cycling and walking on travel intentions and actual behavior. Sustainability (Switzerland), 11(9). Diambil dari https://doi.org/10.3390/su11092554

Ghozali, I. (2009). Aplikasi Analisis Multivariate dengan Program SPSS. Semarang: Badan Penerbit Universitas Diponegoro.

Giménez-Gaydou, D. A., Cupido dos Santos, A., Mendes, G., Frade, I., \& Ribeiro, A. S. N. (2019). Energy consumption and pollutant exposure estimation for cyclist routes in urban areas. Transportation Research Part D: Transport and Environment, 72(April), 1-16. Diambil dari https://doi.org/10.1016/j.trd.2019.04.005

Grigore, E., Garrick, N., Fuhrer, R., \& Axhausen, K. W. (2018). Bikeability in Basel. Arbeitsberichte Verkehrs- und Raumplanung, 1372. Diambil 15 Maret 2020 dari https://doi.org/10.3929/ETHZ-B-000283763

Gutiérrez, M., Hurtubia, R., \& Ortúzar, J. de D. (2020). The role of habit and the built environment in the willingness to commute by bicycle. Travel Behaviour and Society, 20(February), 62-73. Diambil dari https://doi.org/10.1016/j.tbs.2020.02.007

Hopkins, D., García Bengoechea, E., \& Mandic, S. (2019). Adolescents and their aspirations for private car-based transport. Transportation, (0123456789). Diambil dari https://doi.org/10.1007/s11116-019-10044-4

Irawan, M. Z., \& Sumi, T. (2011). Promoting Active Transport in Students' Travel Behavior: A Case from Yogyakarta (Indonesia). Journal of Sustainable Development, 4(1), 45-52. Diambil dari https://doi.org/10.5539/jsd.v4n1p45

Johansson, K., Hasselberg, M., \& Laflamme, L. (2010). Young adolescents' independent mobility, related factors and association with transport to school. A cross-sectional study. BMC Public Health, 10. Diambil dari https://doi.org/10.1186/1471-2458-10-635

Luengo-Oroz, J., \& Reis, S. (2019). Assessment of cyclists' exposure to ultrafine particles along alternative commuting routes in Edinburgh. Atmospheric Pollution Research, 10(4), 1148-1158. Diambil dari https://doi.org/10.1016/j.apr.2019.01.020

Luo, J., Boriboonsomsin, K., \& Barth, M. (2020). Consideration of exposure to traffic-related air pollution in bicycle route planning. Journal of Transport and Health, 16(October 2019), 100792. Diambil dari https://doi.org/10.1016/j.jth.2019.100792

Maciorowski, M. M., \& Souza, J. C. (2018). Urban Roads and Non-Motorized Transport: The Barrier Effect and Challenges in the Search for Sustainable Urban Mobility. Transportation Research Procedia, 33, 123-130. Diambil dari https://doi.org/10.1016/j.trpro.2018.10.084

Malkhamah, S., Tight, M., \& Montgomery, F. (2005). The development of an automatic method of safety monitoring at Pelican crossings. Accident Analysis and Prevention, 37(5), 938946. Diambil dari https://doi.org/10.1016/j.aap.2005.04.012

Menteri Pendidikan dan Kebudayaan Republik Indonesia. Permendikbud Nomor 51 Tahun 2018 Tentang Penerimaan Peserta Didik Baru Pada Taman Kanak-Kanak, Sekolah Dasar, Sekolah Menengah Pertama, Sekolah Menengah Atas, Dan Sekolah Menengah Kejuruan (2018). Diambil dari https://jdih.kemdikbud.go.id/arsip/PERMENDIKBUD NOMOR 51 TAHUN 2018.pdf

Meuleners, L. B., Fraser, M., Johnson, M., Stevenson, M., Rose, G., \& Oxley, J. (2020). Characteristics of the road infrastructure and injurious cyclist crashes resulting in a hospitalisation. Accident Analysis and Prevention, 136(October 2019). Diambil dari https://doi.org/10.1016/j.aap.2019.105407

Ng, A., Debnath, A. K., \& Heesch, K. C. (2017). Cyclist' safety perceptions of cycling infrastructure at un-signalised intersections: Cross-sectional survey of Queensland cyclists. Journal of Transport and Health, 6, 13-22. Diambil dari 
https://doi.org/10.1016/j.jth.2017.03.001

Organization, W. H. (2018). World health statistics 2018: monitoring health for the SDGs, sustainable development goals. Geneva: World Health Organization.

Pitt, T. M., Nettel-Aguirre, A., McCormack, G. R., Howard, A. W., Piatkowski, C., Rowe, B. H., \& Hagel, B. E. (2019). Child and adolescent bicycling injuries involving motor vehicle collisions. Injury Epidemiology, 6(1), 4-10. Diambil dari https://doi.org/10.1186/s40621019-0185-z

Pojani, E., Van Acker, V., \& Pojani, D. (2018). Cars as a status symbol: Youth attitudes toward sustainable transport in a post-socialist city. Transportation Research Part F: Traffic Psychology and Behaviour, 58, 210-227. Diambil dari https://doi.org/10.1016/j.trf.2018.06.003

Sharma, B., Nam, H. K., Yan, W., \& Kim, H. Y. (2019). Barriers and enabling factors affecting satisfaction and safety perception with use of bicycle roads in Seoul, South Korea. International Journal of Environmental Research and Public Health, 16(5). Diambil dari https://doi.org/10.3390/ijerph16050773

Soemitro, R. A. A., \& Suprayitno, H. (2018). Pemikiran Awal tentang Konsep Dasar Manajemen Aset Fasilitas. Jurnal Manejemen Aset Infrastruktur \& Fasilitas, 2(Sup. 1), 1-14. Diambil dari https://doi.org/10.12962/j26151847.v2i0.4225

Stark, J., Berger, W. J., \& Hössinger, R. (2018). The effectiveness of an intervention to promote active travel modes in early adolescence. Transportation Research Part F: Traffic Psychology and Behaviour, 55, 389-402. Diambil dari https://doi.org/10.1016/j.trf.2018.03.017

Suprayitno, H., \& Soemitro, R. A. A. (2018). Preliminary Reflexion on Basic Principle of Infrastructure Asset Management Pemikiran Awal tentang Prinsip Dasar Manajemen Aset Infrastruktur. Jurnal Manajemen Aset Infrastruktur \& Fasilitas, 2(1), 1-10.

Swiers, R., Pritchard, C., \& Gee, I. (2017). A cross sectional survey of attitudes, behaviours, barriers and motivators to cycling in University students. Journal of Transport and Health, 6(July), 379-385. Diambil dari https://doi.org/10.1016/j.jth.2017.07.005

Tamin, O. Z. (2008). Perencanaan, Pemodelan, dan Rekayasa Transportasi. Bandung: Institut Teknologi Bandung.

Terrón-Pérez, M., Molina-García, J., Martínez-Bello, V. E., \& Queralt, A. (2018). Active commuting to school among preschool-aged children and its barriers: An exploratory study in collaboration with parents. Journal of Transport and Health, 8(February 2017), 244-250. Diambil dari https://doi.org/10.1016/j.jth.2017.12.007

Tomtom. (2019). Traffic Index - Traffic results 2019, 21. Diambil dari https://www.tomtom.com/traffic-index/ranking/ 403 results FULL

Wang, Y., Liu, Y., Ji, S., Hou, L., Han, S. S., \& Yang, L. (2018). Bicycle lane condition and distance: Case study of public bicycle system in Xi' an, China. Journal of Urban Planning and Development, 144(2), 1-8. Diambil dari https://doi.org/10.1061/(ASCE)UP.19435444.0000436

Wuerzer, T., \& Mason, S. G. (2015). Cycling willingness: Investigating distance as a dependent variable in cycling behavior among college students. Applied Geography, 60, 95-106. Diambil dari https://doi.org/10.1016/j.apgeog.2015.03.009

Yang, Y., Wu, X., Zhou, P., Gou, Z., \& Lu, Y. (2019). Towards a cycling-friendly city: An updated review of the associations between built environment and cycling behaviors (2007-2017). Journal of Transport and Health, 14(February). Diambil dari https://doi.org/10.1016/j.jth.2019.100613

Zhu, X., \& Yoon, J. (2017). From sedentary to active school commute: Multi-level factors associated with travel mode shifts. Preventive Medicine, 95, S28-S36. Diambil dari https://doi.org/10.1016/j.ypmed.2016.10.018 
(e)ISSN 2615-1847 $\quad$ (p)ISSN 2615-1839

Jurnal Manajemen Aset Infrastruktur \& Fasilitas - Vol. 4, No. 4, Oktober 2020 